\title{
BIOCHAR ADDITION FOR ENHANCED CUCUMBER FRUIT QUALITY UNDER DEFICIT IRRIGATION
}

\author{
ADIÇÃO DE BIOCHAR PARA MELHORAR A QUALIDADE DE FRUTOS DE \\ PEPINO SOB IRRIGAÇÃO EM DÉFICIT
}

\author{
Abubaker, B. ALI ${ }^{* *}$; Nazar A. ELSHAIKH² Gameraldawla HUSSIEN $^{3}$; \\ Farid E. ABDALLAH ${ }^{3}$; Sami HASSAN ${ }^{1}$ \\ 1. Institute of Agricultural Equipment Engineering, Jiangsu University, Zhenjiang, China; 2. Department of Agricultural Engineering, \\ Faculty of Engineering, University of Sinnar, Sudan; 3. Department of Agricultural Engineering, College of Agricultural Studies, Sudan \\ University of Science and Technology, Shambat, Khartoum North, Sudan. abubaker@ujs.edu.cn
}

\begin{abstract}
In the recent years, biochar has been used as an organic soil amendment. Therefore, this study was undertaken in April 2016 to July 2017 to examine the effect of different biochar addition (BA) rates and deficit irrigation (DI) on quality characteristics of cucumber under greenhouse conditions over two consecutive growing seasons. The $\mathrm{BA}$ treatments were $\mathrm{B}_{0}\left(0\right.$-ton ha $\left.{ }^{-1}\right), \mathrm{B}_{1}\left(10\right.$-ton ha ${ }^{-1}$ and $\mathrm{B}_{2}\left(20\right.$-ton ha $\left.{ }^{-1}\right)$, while the DI treatments were $1.0\left(\mathrm{~W}_{1}\right), 0.60\left(\mathrm{~W}_{2}\right)$ and $0.40\left(\mathrm{~W}_{3}\right)$ of the reference evapotranspiration $\left(\mathrm{ET}_{0}\right)$. The results obtained elaborated that the combination of $\mathrm{B}_{2} \mathrm{~W}_{1}$ gave the maximum values of fruit weight $(\mathrm{g})$, fruit water content $(\%)$, fruit dry biomass $(\mathrm{g})$ and $\mathrm{pH}$ in the both seasons. On the other hand, $\mathrm{W}_{2}$ and $\mathrm{W}_{3}$ increased significantly titratable acidity (TA \%) and total soluble solid (TSS \%). It was possible to conclude that BA with DI might be a novel approach to improve both crop yield and fruit quality.
\end{abstract}

KEYWORDS: Biochar. Cucumber. Quality. Irrigation.

\section{INTRODUCTION}

Success of any greenhouse vegetable system relies on the production of greater fruit yields and better fruit quality (RODRIGUEZ et al., 2007). According to CUI; ZHANG (1991), China is the world's biggest producer of cucumber with production reaches to $54.3 \times 10^{6}$ tones representing $76 \%$ of the global production. The total cultivated area is about $23 \times 10^{4}$ ha with total productivity estimated by $30 \mathrm{tha}^{-1} \mathrm{yr}^{-1}$.

The yield and quality of crops are dependent on a number of factors including good land management (soil amendments and the amount of water) and agronomic practices (RAO et al., 2016). Cucumber fruit yields were found to be highly affected by the deficit irrigation (DI) MAO et al. (2003).

Biochar, an organic matter, has been used for soil amendment to improve soil structures and fertility. Biochar amended soils showed advantages due to their carbon stability and releasing nutrients, thus, results in an increased crop productivity and soil production (LIU et al., 2012). Beside biochar addition (BA), DI strategies are considered to save irrigation water as well as sustaining crop production. However, more research is needed for the improvement of DI on vegetables.

The most important quality characteristics for cucumber are the fruit weight, diameter and dry matter of the crop. However, quality may include sensory properties such as appearance, texture, taste and flavor (GO'MEZ-LO'PEZ et al., 2006). In this study, we have hypothesized that BA can be used as organic fertilizer for soil amendment which can mitigate the negative effects of water stress on cucumber plants. Hence, this study aims to investigate the effect of BA along with DI on cucumber fruit quality by estimation of fruit characteristics, quality and sensory evaluation.

\section{MATERIAL AND METHODS}

\section{Study area background}

The experiment was conducted in two successive cropping seasons from $23^{\text {th }}$ April to end of July 2016 and 6 April to $3^{\text {rd }}$ of July 2017, at a permanent site of modern glass greenhouse farm, at the Key Laboratory of Modern Agricultural Equipment and Technology, Jiangsu university, Zhenjiang, China, (Latitude $31^{\circ} 56^{\prime} \mathrm{N}$; Longitude $119^{\circ} 10$ 'E and Altitude $23 \mathrm{~m}$ above mean sea level). The effect of three biochar addition (BA) treatments and three deficit irrigation (DI) on cucumber (Cucumis sativus L.) quality under greenhouse conditions were studied. Two BA rates of $\mathrm{B}_{0}$ (0-ton $\left.\mathrm{ha}^{-1}\right), \mathrm{B}_{1}\left(10\right.$-ton $\left.\mathrm{ha}^{-1}\right)$ and $\mathrm{B}_{2}\left(20\right.$-ton $\left.\mathrm{ha}^{-1}\right)$ along with three DI designated as $\mathrm{W}_{1}, \mathrm{~W}_{2}$ and $\mathrm{W}_{3}$ corresponding to irrigation amount of 1.0, 0.60 and $0.40 E T_{0}$, respectively, were used. The physical and 
chemical properties of biochar are presented in Table 1. The experiment was arranged in a randomized complete block design with split plot arrangements replicated thrice, each replication consisted of nine samples.

Table 1. Biochar characteristics.

\begin{tabular}{ccccccc} 
Properties & $\mathrm{pH}$ & SOC & Total N & Total P & Total K & CEC \\
Average & 10.35 & $467.2 \mathrm{~g} \mathrm{~kg}^{-1}$ & $5.9 \mathrm{~g} \cdot \mathrm{kg}^{-1}$ & $14.43 \mathrm{~g} \mathrm{~kg}^{-1}$ & $11.5 \mathrm{~g} \mathrm{~kg}^{-1}$ & $21.7 \mathrm{cmol} \mathrm{kg}^{-1}$ \\
\hline
\end{tabular}

Note: SOC, Soil organic carbon; CEC, Cation exchange capacity

\section{Measurement of fruit quality}

Cucumber was harvested on $17^{\text {th }}$ July 2016

and $6^{\text {th }}$ June 2017. Data on fruit quality components were measured as, fruit length (FL) and diameter (FD), $\mathrm{pH}$, fruit water content (FWC\%), fruit weight (g), fruit dry biomass (FDB), total soluble solid $\%$ (TSS), titratable acidity (TA\%) and vitamin $\mathrm{C}$ (Vc) in 27 samples of fruit for each treatment. Fruit length $(\mathrm{cm})$ and diameter $(\mathrm{mm})$ were measured by metric bar and vernier calculated as the average of measured values. Fruit weight (g) was determined using a sensitive balance. The FDB samples were labeled and weighed to obtain the fresh biomass then placed in plate and dried at $105^{\circ} \mathrm{C}$ for 24 hours in an oven and then reweighed to obtain the dry biomass.

The $\mathrm{FWC} \%$ in fresh cucumber was conducted in the first stage of drying at the temperature of $105{ }^{\circ} \mathrm{C}$ for 24 hours by means of a laboratory oven. The TSS\% was determined using brix refractometer (ABBE, WYA_2S, USA). pH was measured from juice extracted from 27 peeled fruit using a $\mathrm{pH}-$ meter. The $\mathrm{TA} \%$ was measured according to AOAC (1999).

\section{Sensory evaluation}

The sensory evaluation of marketable fruit yield was conducted using nine-point scale $(9,7,5$,
3 and 1 represent excellent, good, fair, limit of marketability, poor and very poor, respectively) with 10 trained panelists at Jiangsu University. Marketable fruit yield was evaluated based on different parameters such as taste, color, flavor, appearance; texture and overall-acceptance were selected as quality factors for sensory analysis.

\section{Statistical analysis}

The data were statistically performed using SPSS software package for windows (IBM SPSS v. 16). Differences of the means values of parameters were tested by two-way analysis of variance (ANOVA). Differences of means were considered significant at $P \leq 0.05$.

\section{RESULTS}

\section{Fruit quality measured}

Mean values of fruit length (FL) for both $\mathrm{BA}$ and DI are shown in Figure 1A. The combination of $\mathrm{B}_{2} \mathrm{~W}_{1}$ gave the maximum values of 49.7 and $50.2 \mathrm{~cm}$ in the first and second seasons, respectively, not significantly differing from $\mathrm{B}_{2} \mathrm{~W}_{2}$ (46.2 and $46.7 \mathrm{~cm}$, respectively). While, the lowest recorded values of 39.9 and $40.4 \mathrm{~cm}$ were obtained for first and second seasons, respectively, using $\mathrm{B}_{0}$ $\mathrm{W}_{3}$.

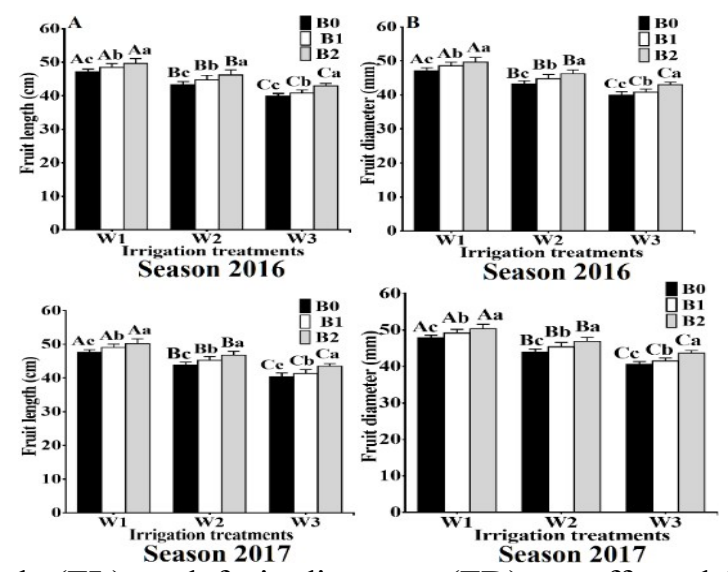

Figure 1. Cucumber fruit length (FL) and fruit diameter (FD) as affected by biochar addition and deficit irrigation.

Note: For figure 1-10; $\mathrm{B}_{0}, \mathrm{~B}_{1}$, and $\mathrm{B}_{2}$ represent $\mathrm{BA}$ rates of 0,10 and 20 ton ha ${ }^{-1}$, respectively. $\mathrm{W}$ denotes the DI treatments $\left(\mathrm{W}_{1}: 1.0\right.$, $\mathrm{W}_{2}: 0.60$ and $\mathrm{W}_{3}: 0.40$ of evapotranspiration $\left(\mathrm{ET}_{0}\right)$. The same letter means not significantly different between BA treatments (upper case) or between DI levels (lower case) at $P \leq 0.05$. 
The highest fruit diameter (FD) values were recorded under $B_{2}$ treatments followed by $B_{1}$ compare to non-amended treatments $\mathrm{B}_{0}$. For DI, sharp reduction in FD was realized under $\mathrm{W}_{3}$ and got improved gradually towards $\mathrm{W}_{1}$ (Figure 1B). Moreover, BA increased FD in all irrigation treatments. Maximum increase was observed with combination of $\mathrm{B}_{2} \mathrm{~W}_{1}$ and $\mathrm{B}_{2} \mathrm{~W}_{2}(49.7$ and $50.7 \mathrm{~mm})$ and $(46.2$ and $46.9 \mathrm{~mm})$ recorded in the both seasons respectively.

\section{Fruit biomass productivity}

On the other hand, the maximum value of fresh fruit weight plant $(\mathrm{g})$ of $214.6 \mathrm{~g}$ was observed in the second season under $\mathrm{B}_{2} \mathrm{~W}_{1}$ followed by $\mathrm{B}_{1} \mathrm{~W}_{1}$ $(205.4 \mathrm{~g})$, both treatments showed significant increase as presented in Figure 2C. However, the minimum value of $92.6 \mathrm{~g}$ was observed under $\mathrm{B}_{0} \mathrm{~W}_{3}$ in the first season.

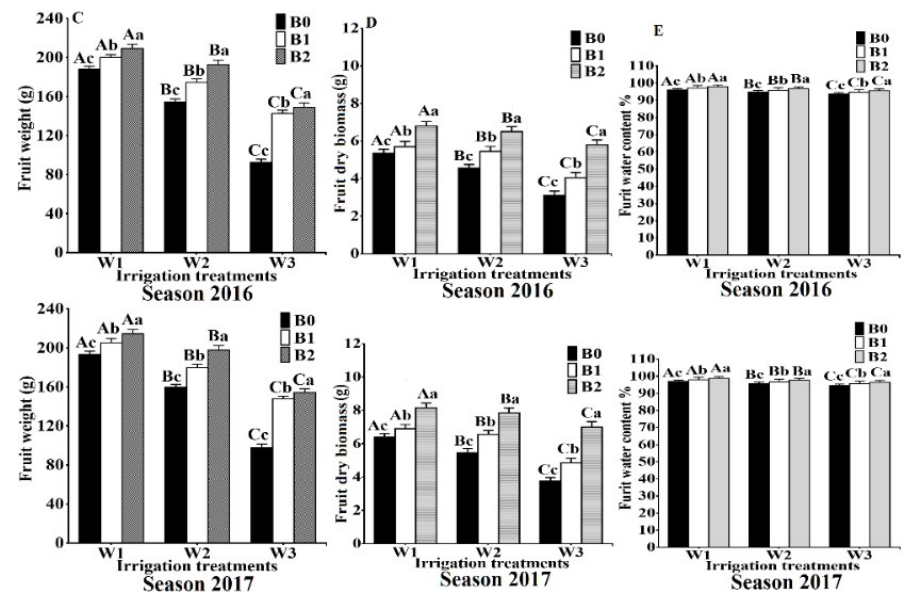

Figure 2. Fruit weight per plant (g), fruit dry biomass (g) and Fruit water content $\%$ as affected by biochar addition and deficit irrigation.

The interaction between $\mathrm{BA}$ rate and DI showed significant difference $(P \leq 0.05)$ on FDB productivity in the first season and highly significant effect $(P \leq 0.01)$ in the second season Figure 2D. In case of high BA rate and DI, FDB content was significantly higher $(P \leq 0.01)$ under $\mathrm{B}_{2} \mathrm{~W}_{1}(6.8$ and $8.15 \mathrm{~g})$ followed by $\mathrm{B}_{1} \mathrm{~W}_{1}(5.7$ and $6.9 \mathrm{~g})$ for both seasons, respectively. Whereas the minimum values of 3.1 and $3.75 \mathrm{~g}$ were obtained by $\mathrm{B}_{0} \mathrm{~W}_{3}$ for the both seasons, respectively.

As shown in Figure 2E, the highest fruit water content $(\mathrm{FWC} \%)$ was achieved under $\mathrm{B}_{2} \mathrm{~W}_{1}$ $(98.9 \%)$ in the second season, while $\mathrm{B}_{0} \mathrm{~W}_{3}$ gave the lowest $\mathrm{FWC} \%$ value of $93.7 \%$ in the first season. Furthermore, there were no significant differences between $\mathrm{B}_{2} \mathrm{~W}_{1}$ and $\mathrm{B}_{2} \mathrm{~W}_{2}$ in the first unlike the second season. Cucumber $\mathrm{FWC} \%$ proportionally decreased with the amount of irrigation and increased with increasing in BA rate.

The highest $\mathrm{pH}$ values were achieved within the highest $\mathrm{BA}$ treatment $\left(\mathrm{B}_{2}\right) . \mathrm{pH}$ value significantly increased when BA rate increased as illustrated in Figure 3F. The highest $\mathrm{pH} \%$ values (6.35 and 6.75\%) and (5.75 and 6.15\%) were obtained from $\mathrm{B}_{2} \mathrm{~W}_{1}$ and $\mathrm{B}_{2} \mathrm{~W}_{2}$, in the both seasons, respectively. TSS\% values were mainly affected by BA $(P \leq 0.05)$; there were slight differences between DI treatments. The $\mathrm{TSS} \%$ values ranged from $2.29 \%$ to $4.02 \%$ for both growing seasons as shown in Figure $3 \mathrm{G}$. The $\mathrm{B}_{2} \mathrm{~W}_{3}$ gave the highest TSS\% followed by $\mathrm{B}_{2} \mathrm{~W}_{2}$; whereas $\mathrm{B}_{0} \mathrm{~W}_{3}$ gave the lowest TSS value. For TA\%, it increased under the lower irrigation treatments $\left(\mathrm{W}_{2}\right.$ and $\left.\mathrm{W}_{3}\right)$ compared to $\mathrm{W}_{1}$ (Figure 3H). Significant increase of TA\% was detected with $\mathrm{W}_{3}$, which gave the maximum TA\% value $(7.25 \%)$ in the first season which was significantly different from the value recorded in the second season $(6.1 \%)$. Another increase of TA\% was observed under different BA treatments, as the greatest $\mathrm{TA} \%$ value was detected in $\mathrm{B}_{2}$ which was significantly higher than $\mathrm{B}_{0}$. Despite the significant increase in TA\% when biochar was added to the soil $(P \leq 0.05)$, the difference was not significant between the $\mathrm{B}_{1}$ and $\mathrm{B}_{2}$ in the both seasons. 
Biochar addition...

ALI, A. B. et al.

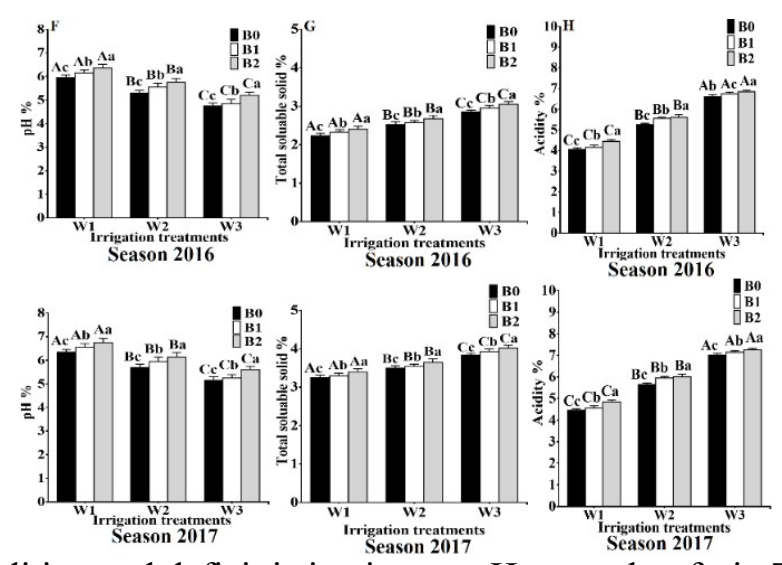

Figure 3. Effect of biochar addition and deficit irrigation on pH cucumber fruit, Total soluble solid (TSS\%) and titratable acidity (TA\%).

As shown in Figure 4I, vitamin $\mathrm{C}\left(\mathrm{V}_{\mathrm{C}}\right)$ increased significantly $(P \leq 0.05)$ under DI treatments $\left(\mathrm{W}_{2}\right.$ and $\mathrm{W}_{3}$ ) compared to the control $\mathrm{W}_{1} . \mathrm{V}_{\mathrm{C}}$ value increased by $55 \%$ and $43.7 \%$ and by $56 \%$ and $44.1 \%$ with respect to $\mathrm{B}_{2} \mathrm{~W}_{3}$ and $\mathrm{B}_{2} \mathrm{~W}_{2}$ in the both seasons, respectively. However, BA showed insignificant increment on $\mathrm{V}_{\mathrm{C}}$ at $\mathrm{W}_{1}$. Nevertheless, the combination of $B_{1} W_{3}$ ranked second to $B_{0} W_{3}$.

As presented in Figure $4 \mathrm{~J}$, there were highly significant differences among treatments in the percentage of marketable fruit. The maximum marketable fruit percentage was recorded for the combination of $\mathrm{B}_{2} \mathrm{~W}_{1}(78.95 \%)$, followed by $\mathrm{B}_{2} \mathrm{~W}_{2}$ $(71.85 \%)$, with a slight difference between $\mathrm{B}_{1} \mathrm{~W}_{1}$ and $\mathrm{B}_{2} \mathrm{~W}_{3}$ in the first season (70.35 and 69.75, respectively), while $\mathrm{B}_{2} \mathrm{~W}_{1}$ gave fairly good marketable yield compared to other treatments in both growing seasons.

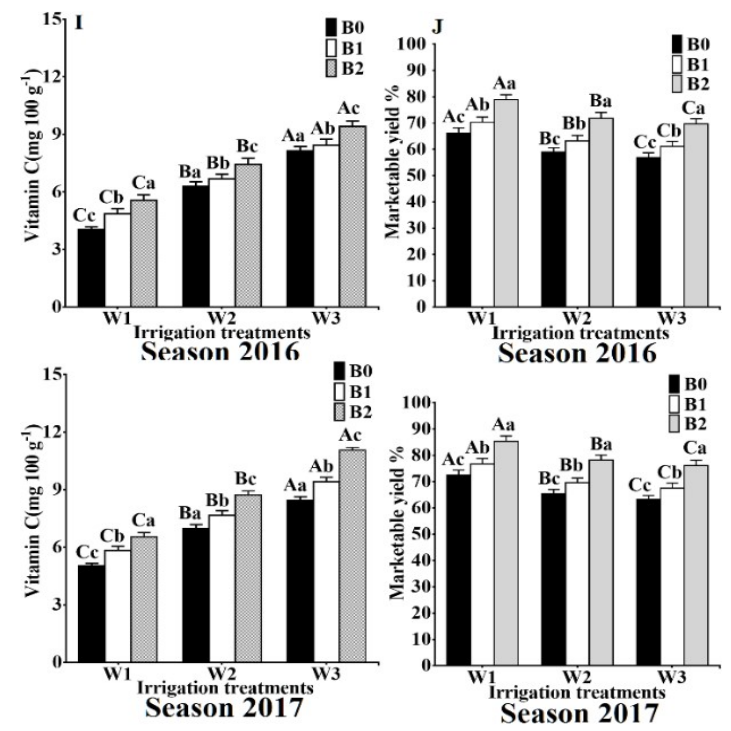

Figure 4. Vitamin $\mathrm{C}$ and fruit marketable yield of cucumber as affected by biochar addition and deficit irrigation.

\section{Fruits sensory evaluation}

The fruits showed the best taste $(7.5$ and $8 \%)$ in the first and $(8.5$ and $8 \%)$ in the second season at $\mathrm{B}_{2} \mathrm{~W}_{1}$ and $\mathrm{B}_{2} \mathrm{~W}_{2}$, respectively, compared with $\mathrm{B}_{0}$ (Figure 5). Fruits color was dark green at $\mathrm{B}_{2}$ and $\mathrm{B}_{1}$ under $\mathrm{W}_{1}$ and $\mathrm{W}_{2}$ compared with $\mathrm{B}_{0}$ (Figure 5 ). The appearance of fruits gave the best evaluation at BA treatments which gave 5.5 and $7.1 \%$ in the both seasons compared with $\mathrm{B}_{0}(4.2 \%)$. Flavor evaluation was affected significantly by DI and insignificantly by biochar treatment. In $\mathrm{W}_{1}$ and $\mathrm{W}_{2}$, flavor was lowered compared to $\mathrm{W}_{3}$. Except for $\mathrm{W}_{1}$, incorporation of biochar increased flavor, however greater response was observed only in the $\mathrm{W}_{1}$ and $\mathrm{W}_{2}$ treatments (Figure 5).

Both BA and DI had a significant effect on texture. Texture was decreased under $\mathrm{W}_{3}$ compared to $\mathrm{W}_{1}$ and $\mathrm{W}_{2}$. However, biochar increased texture in all irrigation treatments. In addition, greater response was observed in the first season at $B_{2}$ 
compared to $\mathrm{B}_{0} ; \mathrm{B}_{2} \mathrm{~W}_{1}$ and $\mathrm{B}_{2} \mathrm{~W}_{2}(8$ and $7.5 \%$, respectively). Results showed that overall acceptance was almost stable and ranged from 3.6 to $6.9 \%$ and 4.5 to $7.7 \%$ in the both seasons, respectively, but thereafter, it decreased sharply in all irrigation treatments. Maximum overall acceptance (7.5 and 7.7\%) for both seasons, respectively, was found in $B_{2}$ treatment under $W_{1}$ which was greater than those of $\mathrm{B}_{1}$ and $\mathrm{B}_{0}$ treatments. In general, biochar treatment enhanced the overall acceptance compared to $\mathrm{B}_{0}$; however, the increase was significant only in $\mathrm{W}_{1}$ and $\mathrm{W}_{2}$.

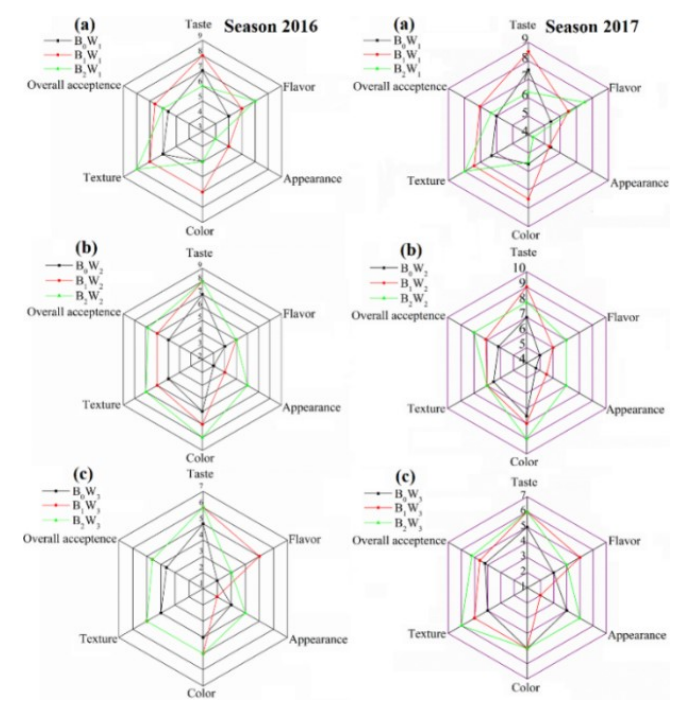

Figure 5. Radar graphic presenting sensory evaluation of cucumber as affected by biochar addition and deficit irrigation.

\section{DISCUSSION}

Generally, deficit irrigation (DI) showed extreme impact on cucumber growth and quality as witnessed by the current results. However, biochar addition (BA) led to great improvement in plant growth and quality. In this context, SAHIN et al. (2015) reported that deficit irrigation (DI) has a significant effect on cucumber. Here in, fruit length and diameter were positively affected by BA and negatively by DI treatments. Similar findings were obtained by AKHTAR et al. (2014) who concluded that BA showed better enhancement in length and diameter of tomato compared to non-biochar. Moreover, (SAHIN et al., 2015) concluded that there were negative effects of water stress on cucumber fruit length and diameter. Our results regarding fruit weight are confirmed by the findings of OFOSU-ANIM AND LIMBANI (2007) who recorded that maximum fruit weight plant $^{-1}$ could reach 376 g. Furthermore, AKHTAR et al. (2014) attributed the increment in fruit weight plant ${ }^{-1}$ to the improvement of plant water status which is mainly associated with BA.

Results indicated the fruit dry biomass (FDB) was positively affected by BA and negatively by shortage in amount of water applied. These results may be attributed to that BA had ability to increase the fruit water content particularly at high
BA rates which enhanced water availability to the plant. Our results agreed with HOSSAIN et al. (2010) who reported that the highest FDB and highest tomato productivity were recorded after BA.

Fruit water content $(\mathrm{FWC} \%)$ is of the main cucumber constituents. Indeed, the $\mathrm{FWC} \%$ of cucumber depends on the environmental conditions and its handling at the period of harvest. The better FWC $\%$ obtained by $\mathrm{B}_{2} \mathrm{~W}_{1}$ may be associated with the increased average weight of fruit $(209.4 \mathrm{~g})$ compared with $\mathrm{B}_{0} \mathrm{~W}_{3}(92.6 \mathrm{~g})$. SERCE; STAUB (1997) reported that, the plants may not show any water stress symptoms of earlier stages, but this would definitely affect the physiological processes and results in poor fruit quality.

The TSS $\%$ of cucumber increased with the increase of irrigation levels from $\mathrm{W}_{2}$ to $\mathrm{W}_{3}$, and also increased with the increase of biochar levels. These results may be due to reduction of $\mathrm{FWC} \%$ under water stress. This is supported by the findings of AGBNA et al. (2017) who found that the TSS increases under water stress, with insignificant effect by BA. Similar results obtained by DORJI et al. (2005) who reported that biochar has no significant effect, meanwhile $20 \%$ higher TSS was recorded under water stress.

Based on our findings, the BA under DI conditions could be a promising strategy to enhance the quality of cucumber crop. Therefore, more 
Biochar addition...

assimilates were directed into the fruits, enhancing the titratable acidity (TA\%). These results could be attributed to that biochar participated in maintaining carbon/nitrogen ratio through providing extra carbon for the production of organic acids such as citric acid and malic acid, which are the main contributors of fruit acidity. AKHTAR et al. (2014) reported that BA improves the root development to deeper layers of the soil which allows uptake of belowground carbon and nitrogen, and other nutrients by the plant. In general, higher fruit $\mathrm{pH}$ values indicate better fruit quality in cucumber. Although water stress led to significant decrease, $\mathrm{BA}$ showed great enhancement in fruit $\mathrm{pH}$. This mainly could be attributed to the fact that water stress reduces the water content in fruits which consequently reduces the $\mathrm{pH}$ value below 6.5 .

Results showed that vitamin $\mathrm{C}(\mathrm{Vc})$ content increased under DI treatments with slight increase by BA. These results are in agreement with the findings of AGABNA et al. (2017) who found that reduced water supply increases $\mathrm{Vc}$ and $\mathrm{TA} \%$ in tomato. Similar revealed that BA leads to increments of TSS\% and Vc under saline and nonsaline irrigation conditions USMAN et al. (2016). Thus, our results suggest that the balance between using DI and BA in terms of yield and yield quality was achieved in $\mathrm{B}_{1} \mathrm{~W}_{2}$ representing the optimum combination in the present study.

In this study, the great marketable yield was obtained via BA while DI showed negative effect. The low marketable yield associated with water stress might be due to the occurrence of some misshapen fruits; some are aborted after emergence, and found to be over-mature within a short time. In contrast, BA induced plants to produce more flowers, as a result, plants have the highest diameter and fruits weight with regular length. The sensory aspects of taste, flavor, appearance, color, texture, and overall-acceptance represent the total sensory evaluation characteristics of the cucumber fruits. The plants treated with BA showed higher total sensory evaluation than that with DI. The low sensory values of lower amount of water could be explained by the fact that water stress provides unfavorable conditions for the plant which contributes to maturity delay and poor quality. Excellent fruits characteristics typically include their dark green color, flavor, and thin texture (PIERCE; WEHNER, 1990). The agronomic advantages of using BA for crops will make them look more green, strong and healthy in quantity and quality. Phenolic compounds are of great importance in many aspects of agricultural foodstuffs, such as nutrition and commercial properties, through their contributions to sensory properties such as color and flavor (PÉREZ-LÓPEZ et al., 2007). Moreover, the poor quality of fruits may be due to the increase of phenolic components in order to limit water stress conditions. This fact was confirmed by the findings of SONNEBERG et al. (2013) who reported that quality and taste of cucumber are affected by the presence of phenolic components. On the other hand, as our results revealed, the fruit appearance is influenced by water stress which might be attributed to accelerated maturation in fruits leading to seed cavities in fruits. This observation confirms the effect of water stress that imposed by moisture deficit. However, the texture was tender, compact and crisp under BA. The color is the first attractive attribute of cucumber and is very important for commercialization. It is an essential parameter of the quality acceptance, and preference of consumers as well as in determining wholesale prices of cucumber. There were significant differences among BA and DI in the color of cucumber fruits, suggesting that they have different botanical origins. Moreover, it is important that cucumber fruit is of uniform shape and having appropriate, regular and equal color (PÉREZLÓPEZ et al., 2007). BA could be a promising culture alternative, particularly in poor soils and the imbalance between water resources and irrigation demands.

\section{CONCLUSION}

In this study, we investigated the combination effect of BA with DI on cucumber fruit quality. The quality parameters considered in this study were fruit length, diameter, fresh weight, dry weight, water content, $\mathrm{pH}, \mathrm{TSS}, \mathrm{TA}, \mathrm{Vc}$ and marketable yield in addition to sensory evaluation. Results obtained indicated that the fruit quality is directly affected by water stress, where deficit in soil moisture led to concentrate the TA in fruit and decreased its water content, fruit length and diameter, which eventually led to sharp reduction in marketable yield. On the other hand, BA compensated the loss in SMC and enhanced the cucumber quality, and subsequently, enhanced the marketable yield. Hence BA could be considered as an effective approach to address water stress and enhances cucumber fruit quality.

\section{ACKNOWLEDGEMENT}

Our thanks to Priority Academic Program Development of Jiangsu Higher Education Institutions (PAPD) for their support. 
RESUMO: Nos últimos anos, o biochar tem sido utilizado como uma alteração do solo orgânico. Desta maneira, este estudo foi realizado entre os períodos de Abril de 2016 a Julho de 2017 para investigar o efeito de diferentes taxas de alteração de biochar e irrigação por déficit (DI) nas características de qualidade do pepino em casa de vegetação durante duas safras consecutivas. Os tratamentos BA foram $\mathrm{B}_{0}\left(0\right.$ ton ha $\left.{ }^{-1}\right), \mathrm{B}_{1}(10$ ton ha ${ }^{1}$ e $B_{2}\left(20\right.$ ton $\left.h^{-1}\right)$, juntamente com três lâminas de irrigação em déficit $\mathrm{W}_{1}, \mathrm{~W}_{2}$ e $\mathrm{W}_{3}$ correspondentes $100 \%$, $60 \%$ e $40 \%$ da $E T_{0}$, respectivamente. Os resultados obtidos mostraram que a combinação de $\mathrm{B}_{2} \mathrm{~W}_{1} \mathrm{forneceu} \mathrm{os}$ valores máximos de peso dos frutos $(\mathrm{g})$, teor de água dos frutos (\%), biomassa seca dos frutos ( $\mathrm{g})$ e $\mathrm{pH}$ nas duas safras. Por outro lado, $\mathrm{W}_{2}$ e $\mathrm{W}_{3}$ aumentaram significativamente a acidez titulável (TA\%) e o sólido solúvel total (TSS\%). Foi possível concluir que a alteração de biochar com DI pode ser uma nova abordagem para melhorar tanto a produtividade como a qualidade dos frutos.

PALAVRAS-CHAVE: Biochar. Qualidade. Irrigação. Pepino.

\section{REFERENCES}

AGBNA, G. H.; DONGLI, S.; ZHIPENG, L.; ELSHAIKH, N. A.; GUANGCHENG, S.; TIMM, L. C. Effects of deficit irrigation and biochar addition on the growth, yield, and quality of tomato. Scientia Horticulture, v. 222, p. 90-101, 2017. https://doi.org/10.1016/j.scienta.2017.05.004

AKHTAR, S.S; LI, G.; ANDERSEN, M.N.; LIU, F. Biochar enhances yield and quality of tomato under reduced irrigation. Agricultural Water Management, v. 138, p. 37-44, 2014.

https://doi.org/10.1016/j.agwat.2014.02.016

AOAC. Association of Official Analysis Chemists. Official methods of analysis $15^{\text {th }}$ Edition. Artington Vergenia, U.S.A, 1990.

DORJI, K.; BEHBOUDIAN, H.; ZEGBE-DOMÍNGUEZ, A. Water relations, growth, yield, and fruit quality of hot pepper under deficit irrigation and partial root zone drying. Scientia Horticulture, v. 104, p. 137-149, 2005. https://doi.org/10.1016/j.scienta.2004.08.015

GÓMEZ-LÓPEZ, D.; FERNÁNDEZ-TRUJILLO, P.; BAILLE, A. Cucumber fruit quality at harvest affected by soilless system, crop age and preharvest climatic conditions during two consecutive seasons. Scientia Horticulture, v. 110, n. 1, p. 68-78, 2006. https://doi.org/10.1016/j.scienta.2006.06.021

HOSSAIN, M.K., V. STREZOV, K.Y. CHAN AND P.F. NELSON. Agronomic properties of wastewater sludge biochar and bioavailability of metals in production of cherry tomato (Lycopersicon esculentum). Chemosphere, v. 78, p. 1167-1171, 2010. https://doi.org/10.1016/j.chemosphere.2010.01.009

MAO, X., M. LIU, X. WANG, C. LIU, Z. HOU, Z. SHI. Effects of deficit irrigation on yield and water use of greenhouse grown cucumber in the North China Plain. Agricultural Water Management, v. 61, p. 219-228, 2003. https://doi.org/10.1016/S0378-3774(03)00022-2

OFOSU-ANIM, J.; LIMBANI, V. Effect of intercropping on the growth an yield of cucumber (Cucumis sativus L.) and okra (Abelmoschus esculentus L. M ench). International journal of agriculture \& biology, v. 9, n. 4, p. 594-597, 2007.

PÉREZ-LÓPEZ, J.; DEL AMOR, M.; SERRANO-MARTÍNEZ A.; FORTEA, I.; NÚÑEZ-DELICADO, E. Influence of agricultural practices on the quality of sweet pepper fruits as affected by the maturity stage. Journal of the Science of Food and Agriculture, v. 87, n. 11, p. 2075-2080, 2007. https://doi.org/10.1002/jsfa.2966

PIERCE, K.; WEHNER, C. Review of genes and linkage groups in cucumber. HortScience, v. 25, n. 6, p. 605615, 1990. https://doi.org/10.21273/HORTSCI.25.6.605 
RAO, S.S., S.P.S. TANWAR AND P.L. REGAR. Effect of deficit irrigation, phosphorous inoculation and cycocel spray on root growth: seed cotton yield and water productivity of drip irrigated cotton in arid environment. Agricultural Water Management, v. 169, p. 14-25, 2016.

https://doi.org/10.1016/j.agwat.2016.02.008

RODRIGUEZ, J.C., SHAW, N.L. AND D.J. Cantliffe. Influence of plant density on yield and fruit quality of greenhouse-grown Galia muskmelons. HortTechnology, v. 17, n. 4, p. 580-585, 2007.

https://doi.org/10.21273/HORTTECH.17.4.580

SAHIN, U.; KUSLU, Y.; KIZILOGLU, M. Response of cucumbers to different irrigation regimes applied through drip-irrigation system. Journal of Animal and Plant Sciences, v. 25, n. 1, p. 198-205, 2015.

SERCE, S. AND J.E. STAUB. Effects of Water Stress on Fruit Quality in Cucumber. Report-Cucurbit Genetics Cooperative, 20, pp: 11-12, 1997.

SONNEBERG, D., P.A. NDAKEDEMI, AND C.P. LAUBSCHER. The effects of various drip fertigated water quantities on flavonoid and anthocyanin content on hydroponically cultivated (Cucumis sativa L.).

International Journal of Physical Sciences, v. 8, p. 1012-1016, 2013. https://doi.org/10.5897/IJPS2013.3845

USMAN, A.R.A., M.I. AL-WABEL, A.H. ABDULAZIZ, W.A MAHMOUD, A.H. EL-NAGGAR, M. AHMAD, A.F. ABDULELAH AND A.O. ABDULRASOUL. Conocarpus biochar induces changes in soil nutrient availability and tomato growth under saline irrigation. Pedosphere, v. 26, n. 1, p. 27-38, 2016. https://doi.org/10.1016/S1002-0160(15)60019-4

LIU, H.; HAN, P.; ZHANG, C. Effect of biochar on soil aggregates in the loess plateau: results from incubation experiments. International journal of agriculture \& biology, v. 14, n. 6, p. 975-979, 2012. CUI, H.; ZHANG, X. Cucumber cultivar improvement in the People's Republic of China. Cucurbit Genetics Cooperative Report, v. 14, p. 5-7, 1991. 